Vol. 2 No. 2

December 2020

\title{
CHILD ABUSE EXPERIENCED BY THE MAIN CHARACTER IN RAINBOW ROWELL'S ELEANOR AND PARK: A PSYCHOSOCIAL ANALYSIS
}

\author{
Arani Lintang Kinanti \\ Universitas Ahmad Dahlan, Yogyakarta, Indonesia \\ alintangk4@gmail.com \\ Resneri Daulay \\ Universitas Ahmad Dahlan, Yogyakarta, Indonesia \\ resneri.daulay@enlitera.uad.ac.id
}

\begin{abstract}
This research entitled Child Abuse Experienced By The Main Character In Rainbow Rowell's Eleanor And Park: A Psychosocial Analysis. Eleanor and Park was a coming-of-age novel written by Rainbow Rowell. Eleanor, one of the main characters, had a lot of things going on in her life, she lived in poverty and had to deal with child abuse everyday. This research was aimed to identify what kind of abuse Eleanor experienced and to analyze how the abuse affected Eleanor's psychosocial development. This research was classified into a qualitative research. The data were taken from the novel Eleanor and Park written by Rainbow Rowell. In analyzing the data, the researcher applied four out of eight stages of psychosocial development theory by Erik H. Erikson while trying to classify different types of abuse that Eleanor experienced. The data were in descriptive form which was why the analysis is enlighten by the researcher in descriptive way. The result of this research showed that Eleanor had troubles passing psychosocial development stages due to what she had been through in her home life. She might succeed in Early Childhood stage but since living with her step-father, Richie, and receiving many types of child abuse from him such as physical abuse, sexual abuse, psychological abuse and child neglect, she failed to pass three later the stages. In consequence, she grew many unhealthy personalities and getting more distant with people in society. Nonetheless, ever since she met Park, she changed to be a better person, although it took her some time. The story ended without the researcher knowing if she passes the adolescence stage successfully. Therefore, there was still possibility for her to pass later stages well and be a healthy individual.
\end{abstract}

Keywords: psychosocial development, child abuse, psychoanalysis 


\section{INTRODUCTION}

Eleanor and Park is a coming-of-age novel written by Rainbow Rowell and was published in 2012. The story is basically about romance between two teenagers in 1980s, Omaha, Nebraska. The book is not only about romance but also about how the main characters, Eleanor and Park, are trying to get through their own struggles while growing up. Eleanor has a lot of things going on in her life, she lives in poverty and has to deal with domestic abuse everyday. While Park, a half-Korean comic book-lover, is trying to figure his life and himself out.

In the story of Eleanor and Park there is an act of domestic violence. The definition of domestic violence itself is when a person uses abusive behavior to control a partner or other family member. The abuse can be physical, emotional, economic, or sexual. It can affect people of any age, sex, culture, or class (medlineplus.gov, 2017)

Domestic violence has existed in almost all societies throughout history and if In domestic violence if it involves the children it becomes child abuse. The definition of child abuse itself, according to The Child Abuse Prevention and Treatment Act (CAPTA) (in Doak, 2007) is any act or failure to act, on the part of a parent or caretaker, which results in death, serious physical or emotional harm, sexual abuse or exploitation, or an act or failure to act which presents a forthcoming risk of serious harm.

Living in a home where domestic violence happens, children's mental and physical wellbeing can be affected by it, as well as their behavior. Children have been subject to abuse by their parents or other adults since a long time ago. Throughout the centuries, laws have failed to protect children from abuse. But as years passed the laws have evolved, all countries have enacted laws and policies for the protection of children from abuse and neglect.

Child abuse occurs anywhere in the world. For example, in the United States each year more than 3.6 million reports of child abuse are made which involve almost 6 million children. Indonesia is not an exception, in Indonesia got many cases of violence involving children. Rita Pranawati, the deputy chairwoman of the National Commission for Child Protection (KPAI), said there are only some of the cases of violence against children that were exposed and reported by the media. From January to May 2019, Pranawati said the commission received more than 1,000 reports of violence, including physical, psychological or sexual abuse. (Siddharta, 2019)

In the novel, Eleanor, one of the main characters happens to have to go through domestic violence, child abuse in particular. It's good that the book was raising awareness about domestic violence and how the characters have to cope with it. By bringing up topic about domestic violence, Rowell makes the readers more aware about this issue. Especially when domestic violence could be happening anywhere around us, therefore, this issue is worth to be analyzed. In this study, the researcher wants to explore about child abuse and how it affects the victim of abuse's personality by using the Psychosocial Development theory by Erik H. Erikson.

\section{LITERATURE REVIEW}

Researcher found some related studies about this book that have been done before by researchers in a form of thesis and journal. First, research by Dwiki Prenandita (2016) from Universitas Sanata Dharma with Park's Motivation to Help Eleanor in Her Teenage Life Struggle as Seen in Rowell's Eleanor and Park used as 
his thesis' title. Second, a research by Inke Yudhitia Savitri (2016) from Universitas Airlangga entitled Eleanor's Responses toward Domestic Violence in Rainbow Rowell's Eleanor and Park: Feminist Criticism in Children Literature. Third, Katrin Rahma Pandansari (2014) from Universitas Negeri Yogyakarta entitled her research, The Cause and Effect in Melinda's Traumatic Experiences: $A$ Psychosocial Analysis in Anderson's Speak. Fourth, it's a journal from Ersyad Hamzah (2016), Universitas Negeri Surabaya. With Psychosocial Crisis of Elizabeth Gilbert in Eat, Pray, Love as his title.

Some researchs have similarities but there are also some things that differentiate one from the other. Some of them, for example Prenandita and Savitri analyzed the book Eleanor and Park by Rowell's with different focus and theory, meanwhile Pandansari and Hamzah the same theory and approach but analyzing different objects. However, in this research the researcher wants to analyze Rowell's Eleanor and Park, focusing on how child abuse affects the main character, Eleanor, in psychosocial development perspective by using Erikson's theory.

\section{METHODOLOGY}

This research is classified into qualitative research and the data in this research is also in qualitative form. Qualitative research is a method focusing on interpreting its subject matter (Denzin and Lincoln, 1994: 2). In analyzing the novel, there are two kinds of data in this research, primary source and secondary source. The primary source is taken from the novel Eleanor and Park by Rainbow Rowell. The secondary source is taken from some relevant books, academic writings, reviews, discussion and articles on the internet, etc.
There are some steps to reveal the answer of the formulated problem. First step, the researcher read the book carefully and reread several times to take some notes and data that will support the analysis. Second step, the researcher formulated the problems and found the right approach which was suitable for analyzing the problems. In this case, the researcher has already decided to use psychological approach. Therefore, the researcher will focus on the psychological side in the actions of the said character.

After the data are collected, the researcher analyzes the events or the phenomena and the behavior of the character, Eleanor, in the novel and try to find the answer to the formulated problems by using the collected data. The research from the novel Eleanor and Park is conducted to analyze the psychosocial development of the main character, Eleanor. In order to know Eleanor's psychosocial development, the researcher needs to understand Eleanor's feeling and thoughts. According to Doak (2007), there are four types of child maltreatments, they are physical abuse, sexual abuse, psychological abuse and child neglect, wherefore in this study, the researcher tries to classify the types of child abuse that she experienced as well. The researcher takes some times to reread the novel trying to relate the events in the novel to Erikson's psychosocial development theory and to figure out the effects of experiencing abuse on her psychosocial development. The last step was making a conclusion based on the answers of the formulated problems. 


\section{RESULT AND DISCUSSION}

\subsection{The Psychosocial Development of Eleanor}

1. Psychosocial stage 2 - Autonomy vs. Shame and Doubt

Eleanor's parents are not really good at taking care of their children but at least her parents give enough attention of her well-being. At one hand, Eleanor's mom, Sabrina seems to be a kind and loving woman. When Eleanor was a little girl she used to look at her mother as if she was a queen of some fairy tale (Rowell, 2012: 19). On the other hand, Eleanor's dad is a distant figure for her, he's there but he doesn't care enough about Eleanor. According to Doak (2007), what Eleanor's father did to her is an act of negligence and it considers as one of the types of child abuse. During this stage despite the lack of affection from her father, her mother, Sabrina always seems to make sure that Eleanor feels safe, loved and well-treated and it seems enough for Eleanor's personality growth. Although Eleanor's dad is not always there for here in this period, her dad sometimes taught Eleanor one or two things and Eleanor learned to be fond of.

For such a little act from her father, Eleanor learned to trust herself, she gets the confidence of being able to handle things on her own. to Even at this age she has learned that she can't depend herself on her father and mother, knowing that both of Eleanor's parents are not the type of overprotective and who love to spoil their children, the act actually gave Eleanor the right amount of freedom to evolve, Eleanor managed to grow up with a sense that she can take care of herself and manage to do things on her own - the sense of autonomy.
2. Psychosocial stage 3 - Initiative vs. Guilt

During this stage Eleanor already has other siblings, so her mother has to divide her attention to them. Eleanor also sometimes babysits her siblings and plays with them when her mother has other things to do (Rowell, 2012: 34). At such young age Eleanor is able to look after her younger siblings, it shows how Eleanor has gain her mother's trust in taking responsibility of the things she does. Growing up as the oldest, Eleanor's siblings always look up to her. Eleanor was close to her siblings, and they were always on her side on hating their stepfather. Things had changed though after Richie kicked her out the house, her siblings were starting to call Richie "dad" because Richie took pleasure from it. Even when she returned home, they barely welcomed her, "But when Eleanor walked in the house, it was like her siblings didn't recognize her (Rowell, 2012: 18). Despite their cold behavior toward Eleanor, Eleanor often serves as their main support when Richie's abuse happens. Although she is not that close to her siblings anymore, she knows that they are still depending on her and Eleanor does care about them even though she doesn't show it often and she feels like she should protect them from Richie's wrath and she would if only she could. This is where she feels guilty of not being able to help her siblings much.

Her fear of getting on Richie's bad side takes over her, she knows she can't do anything much to protect her siblings even her mother has failed to protect her from Richie, in fact, her mother has to send her away and abandon her at her mother's friends for a year. Eleanor is disappointed that her mother can't stand up for herself let alone for Eleanor. After she returns 
home she promise her mom to be at her best behavior and stay low.

The impact of being force to stay invisible at her own house, so she would not rise Richie's temper is suppressing Eleanor from expressing herself more, this kind of act could be called as a psychological abuse according to Doak (2007). The sense of initiative that she has before Richie comes is long gone and replaced with guilt, self-doubt and lack of initiative. Eleanor starts to build a wall around herself and becomes a closed-off person.

"Their mother shrieked, two rooms away, and they all five jumped together. If this had happened two summers ago, Eleanor would have run and banged on the door herself. She would have yelled at Richie to stop. She would have called 911 at the very, very, very least. But now that seemed like something a child would do, or a fool." (Rowell, 2012: 44)

Moreover, from the data above, it can be seen that Eleanor restrains the urge to call out for help when her mother is being abused by Richie. She believes here that no one can actually help them, she also doubts herself that she can defend Sabrina from the abuse, and that is why Eleanor decides to just keep silent. This also explains that her old self was brave enough to stand against Richie but after have been kicked out, all she feels is a sense of guilt over self-initiated activities.

From the explanation above, it shows the failure of previous and this stage, the lack of trust Eleanor has, makes her reluctant to open up to anyone and the lack of initiative to try doing something. Therefore, the outcome of Eleanor's psychosocial development in this stage is guilt.

3. Psychosocial stage 4 - Industry vs. Inferiority

Eleanor's mother and her stepfather don't care about her education, as long as she stays at school and passes the grades then her parents assume that everything is fine. They never bother to ask about how she is doing at school, whether she has favorite subjects or not, or does she join any extracurricular at school or not, they never care about any of those. In many cases, abused and neglected children are at higher risk for lower academic achievement. However, despite having been through a lot at home, Eleanor is actually doing great at school. She has good grades and teachers seem to always compliment her.

"I've been talking to your teachers,' Mrs. Dunne said. 'Did you know you're getting As in almost all your classes?" (Rowell, 2012: 72)

"Mr. Stessman kept trying to draw her out - she was his new favorite target whenever things got sleepy in class. Today they were supposed to be discussing Romeo and Juliet, but nobody wanted to talk." (Rowell, 2012: 40)

From the data above, it shows that Eleanor always gets her teachers attention at class because she is actually a bright student. It can be said that Eleanor has the ability to be good at academic stuff and she has no problem showing the sense of industry. Nonetheless, Eleanor has inner struggle, she never has the will to participate in class unless her teacher makes her to. This happens because of the 
feeling of shame and doubt from the previous stages of psychosocial development. Eleanor cannot develop much sense of industry because she feels hopeless and inferior. She never thinks of herself as a bright person, she feels unconfident and incompetence therefore she never really participates in class. Her friends who think that she is smart are scared to praise her because they think she is weird and that is also why they hesitate to approach her resulting in Eleanor having only two friends and lead her to not being able to develop the sense to work and develop with others.

In conclusion, Eleanor passed this stage with a sense of inferiority.

4. Psychosocial stage 5 - Identity vs. Role Confusion

In this stage Eleanor has problems with finding her identity. She doesn't know what she wants to be, doesn't know what she wants, doesn't have any plan of the future, her life is more complicated to think about it. All Eleanor could ever think about is surviving.

Having to deal with abusive step-father every day, Eleanor already developed many unhealthy personalities as the consequence of failing previous psychosocial development's stages. Eleanor's past experiences shapes her personality in the present life, some of them are:

a. Closed-Off

"At least he didn't ever talk to her.
Or look at her." (Rowell, 2012: 24)
"I hate meeting new people."
(Rowell, 2012: 111)

Eleanor doesn't really like meeting new people moreover making friends with anyone. Eleanor avoids any kind of interaction, she limits her circle of friends and thinks it's better to stay away from people.

\section{b. Paranoid/Anxious}

Eleanor could no longer trust her mother when she fails protecting Eleanor from Richie's outrage, making Eleanor leaving the house for a whole year and it traumatized her.
"Because my step-dad would kill me." (Rowell, 2012: 96)
"Because he's a bad person. Just ... trust me. He's the kind of bad that tries to kill anything good. If he knew about you, he'd do whatever he could to take you away from me." (Rowell, 2012: 101).

Furthermore, Eleanor always worried about her step-father's presence in her life. She knows that Richie is a terrible person after everything he has done to her, how bad he treats her as a step-child. she thinks that Richie is a walking, tickingbomb, she feels something worse than she could ever imagine will come in her way sooner or later because of him. This is why Eleanor always seems anxious about everything and she tends to put her guard up every time.

c. Weird
"Jesus, was she weird. Today she was dressed like a Christmas tree, with all this stuff pinned to her clothes, shapes cut out of fabric, ribbon ..." (Rowell, 2012: 25)

In the story Eleanor is described as a weird person. She likes to wear weird clothes and strange accessories. Usually teenagers around her age would dress themselves with the trend that's happening, so they will fit in better in the society. On the other hand, Eleanor 
dresses herself however she wants to, she doesn't go with the trend. By wearing unmatched clothes and some weird accessories she actually attracts people's attention, and it makes her stand out even more. She does that not for the attention, but to give a signal that she doesn't want to fit in and mingle with people. She likes it better if people stay out of her business.

\section{d. Insecurity/Unconfident}

Eleanor has many insecurities, one of them comes from the way she looks. She always comparing herself to her mother that she considered as a beauty, not like her and to other girls her age.

"Eleanor looked like her mother through a fish tank. Rounder and softer. Slurred. Where her mother was statuesque, Eleanor was heavy. Where her mother was finely drawn, Eleanor was smudged." (Rowell, 2012: 19)

"Eleanor hated her legs even more than she hated the rest of her body." (Rowell, 2012: 24)

Moreover, people at school especially the girls, like to make fun of Eleanor's appearance. They call her many names, body-shamed her and bully her.

All of the personalities explained above are the result of being abused by her stepfather, Richie, at home. Based on the psychosocial theory by Erikson, failure in some stages of psychosocial development would have impacts in one's personality. In Eleanor's case, she grows up in a toxic household. When she was still living with both of her biological parents, they barely gave her affection she needed, then when her mother remarried with Richie, Eleanor has to deal with his abusive behavior every day. Seeing what Eleanor has been through, it is so likely if she has those harmful personalities that could damage her mentally. If Eleanor can resolve her crisis during this stage, she will develop to be a person with a strong sense of self and feeling of independence and be in control. Eleanor's failure in some stages of psychosocial development might can be fixed at later stages.

\subsection{The Abuse Eleanor Experiences}

According to Doak (2007), there are four types of child abuse; physical abuse, sexual abuse, psychological abuse, and child neglect. In Eleanor's case she experienced all those kinds of abuse.

1. Physical abuse

"He was on her before she could brace herself, tearing the typewriter from her hands and throwing it into the wall so hard it broke through the plaster and hung for a moment in the lath." (Rowell, 2012: 136)

Richie was so mad that day when he kicked Eleanor out because of the noise Eleanor made when she was writing song lyrics on her typewriter. Fortunately, Eleanor's mother was there and she kept pulling Eleanor so she could get away. Although no physical harm was done to Eleanor, Richie had intention to lash out on her physically, if it was not because of her mother, Eleanor surely would be harmed. Eleanor successfully got away from her stepfather but she had to stay at family's friend house for a year because of that. This traumatic event surely makes Eleanor afraid to come home.

\section{Sexual Abuse}

Richie always left inappropriate words on Eleanor's books. At first she doesn't know that it was him, however, in the end of story Eleanor finally found out that it 
was her step-father, Richie's handwriting all along he was the one that always left those crude notes on her books. She also had a moment of epiphany in which she realized all the predatory behavior Richie had been showing toward her such as wanting to know her whereabouts, commenting on her appearance, monitoring her every moves, and even keeping a door off of the bathroom. Eleanor was terrified and thought if she stayed any longer, it's only a matter of time before Richie assaulted her physically. At the end of the story, Eleanor decided to run away from home again and asked for help from distant relatives rather than risk being further victimized.

\section{Psychological Abuse}

Eleanor has been through a lot, she always lives in constant fear because of her abusive stepfather. Eleanor tends to keep everything to herself of what is going in her life, she is afraid if she lets herself to be open, Richie will just take everything from her, everything she loves that is why she spends most of her time at home trying to be as invisible as possible.

The peak of it all was when Richie found out about Park and Eleanor. Richie broke all the things Eleanor has from Park (Rowell, 2012: 243). Eleanor was scared to death that her stepfather would kill her, she ran away from home for the second time because of the same reason, Richie.

\section{Child Neglect}

In the beginning of the novel, she's just moved home after having been kicked out of the house for a year for standing up to Richie (Rowell, 2012: 18). Eleanor is being neglected by her mother when she is living with the Hickmans. Eleanor has never felt comfortable in a house, her environment is too toxic for her and it is not good for the growth of her personality. Moreover, although her mom is kind to Eleanor, she is still not strong enough to defend her own children and she can't even stand up for herself against Richie. The main father figures in Eleanor's life are either absent or abusive. Eleanor father abandoned his own family and even gets married to another woman, and Richie, her stepfather, is emotionally and physically violent.

\section{CONCLUSION}

Eleanor is a sixteen years old girl whose life full of misfits and struggle. According to her age, she is in the adolescence stage of psychosocial development. In the story, the researcher gets a glimpse of Eleanor's childhood life, in the stage of Early Childhood of psychosocial development, Eleanor experiences a good, simple life with both of her parents. As a result, Eleanor passes the early childhood successfully.

In the preschool stage, Eleanor already has other siblings. At first, she is doing fine building her sense of initiative as she is able to act independently and capable to make social interactions. But then Richie comes into her life, damaging her mentally and emotionally. Eleanor lost her trust in other people, her sense of autonomy and her sense of initiative. Therefore, the outcome of this stage for Eleanor is a sense of guilt. Later in school age stage of psychosocial development, Eleanor is known as a bright student but the failure from previous stages affecting her social life. Consequently, she is unable to build a sense of industry due to her emotional problems. In consequences, Eleanor passed this stage with a sense of inferiority.

The last stage of psychosocial development to be analyzed from the novel Eleanor and Park is the adolescence 
stage. At this age, Eleanor has developed many unhealthy characteristics such as a closed off person, weird girl, anxious and unconfident. Although Eleanor has some difficulties and failed in some earlier stages of psychosocial development, she still has the chance to change for the better in later stages. The story ends before the researcher could see if Eleanor passes the adolescent stage successfully or not.

Eleanor always has a hard time passing the psychosocial development by Erikson because she is struggling at home. Family has the main role in shaping one's personality and home should be a safe place for one to grow up, but not everyone can experience a good condition at home. In Eleanor's case, she receives abuse from Richie and it affects her psychosocial development. According to Doak (2007), there are four types of child maltreatment; physical abuse, sexual abuse, psychosocial abuse and child neglect. Unfortunately for Eleanor, she experiences all those types of child abuse.

\section{REFERENCES}

Ahmadi, Abu. Psikologi Umum. Surabaya: Bina Ilmu Offset. 1983.

Boeree, George C. Dr. "Personality Theories." 2006.

Denzin, Norman K., \& Lincoln, Yvonna. S. Handbook of Qualitative Research. USA: Sage Publications. 1994

Dindavika, Fabiana Ellisa. "Finding Self Identity Through The Main Characters and Setting in Rowell's Eleanor and Park". Universitas Sanata Dharma. 2018.

Doak, Melissa J. Child Abuse and Domestic Violence. Texas: Information Plus. 2007.
Erikson, Erik H. Childhood and society. London. Paladin. 1977.

Fleming, James S. "9. Erikson's Psychosocial Developmental Stages". 2004.

Hamzah, Ersyad. "Psychosocial Crisis of Elizabeth Gilbert in Eat, Pray, Love". Universitas Negeri Surabaya. 2016

Hasanah, Uswatun. "The Character Development of Hollis Woods in The Novel Pictures of Hollis Woods". Universitas Ahmad Dahlan. 2018

Jiwanti, Atikah Arum. "Child Abuse as Seen in Constance Briscoe's Ugly: A Psychological Approach." Universitas Ahmad Dahlan. 2009

Kusumawardana, I Made Bayu. "A Study on Relationships between Batman and Hush in Batman Hush: A Psychosocial Approach." 2012.

Marcia, James E. "Identity in adolescence." Handbook of adolescent psychology 9.11. 1980

Minderop, Albertine. Psikologi Sastra. Jakarta: Yayasan Pustaka Obor Indonesia, 2013

Pandansari, Katrin Rahma. "The Cause and Effect in Melinda's Traumatic Experiences: A Psychosocial Analysis in Anderson's Speak." Universitas Negeri Yogyakarta. 2014

Prenandita, Dwiki. “Park's Motivation to Help Eleanor in Her Teenage Life Struggle as Seen in Rowell's Eleanor and Park". Universitas Sanata Dharma. 2016

Septyani, Nur Dwi. "Psychological Develepment of the Main Character in Natsume Soseki's 
Botchan." Universitas Ahmad Dahlan. 2018

Wellek, Rene and Warren, Austin. Theory of Literature. London: Johnathan Cape. 1954

Yudhitia, Inke Savitri. “Eleanor's Responses toward Domestic Violence in Rainbow Rowell's Eleanor and Park: Feminist Criticism in Children Literature." Universitas Airlangga. 2016.

\section{Online Sources}

"Child Abuse Background and History." family.findlaw.com. Findlaw., Nd. Accessed 1 November 2019.

David L, "Identity Status Theory (Marcia)," in Learning Theories, learningtheories.com, July 23, 2014. Accessed 5 November 2019.

J. Vorvick, Linda "Domestic Violence: MedlinePlus Medical Encyclopedia." MedlinePlus.gov, U.S. National Library of Medicine, 8 Mar. 2018. Accessed 28 Oct. 2019.

Rowell, Rainbow. Eleanor and Park. Orion Books, 2012. www.orionbooks.co.uk

Rowell, Rainbow. "FAQ" rainbowrowell.com. Np., Nd. Accessed 1 November 2019.

Siddharta, Amanda. "Physical, Sexual Violence Against Children Surging in Indonesia." Voanews.com, VOA, 4 Aug. 2019. Accessed 5 November 2019.

Cherry, Kendra. "Industry vs. Inferiority Is Stage Four of Psychosocial Development." www.verywellmind.com, 14 Apr. 2020. Accessed 6 June 2020 